\title{
EFFECT OF TURMERIC (CURCUMA LONGA) SPICE ON NUTRITITIONAL, MICROBIAL CONTENT OF MOIN-MOIN AND EFFICACY OF SPICE AGAINST SELECTED FOODBORNE PATHOGENS
}

\author{
Ajayi Olasunmbo A.* and Segun-Taiwo B. A. \\ Food Science and Technology, College of Agriculture, engineering and Science, Bowen \\ University, P. M. B. 284, Iwo, Osun State, Nigeria. \\ *E-mail: olasunmbo.ajayi@bowen.edu.ng
}

Cite this article:

Ajayi O.A., Segun-Taiwo B.A. (2021), Effect of Turmeric (Curcuma longa) Spice on Nutrititional, Microbial Content of MoinMoin and Efficacy of Spice Against Selected Foodborne Pathogens. African Journal of Agriculture and Food Science 4(3), 28-40. DOI:

10.52589/AJAFS-8VINVY88.

\section{Manuscript History}

Received: 2 June 2021

Accepted: 5 July 2021

Published: 20 July 2021

Copyright $\odot 2020$ The Author(s). This is an Open Access article distributed under the terms of Creative Commons AttributionNonCommercial-NoDerivatives 4.0 International (CC BY-NC-ND 4.0 ), which permits anyone to share, use, reproduce and redistribute in any medium, provided the original author and source are credited.
ABSTRACT: Turmeric (Curcuma longa) impacts flavor, organoleptic quality of foods and contributes to the preservation of foods. Moin-moin is an indigenous food made from beans (Vigna unguiculata) and highly perishable. This study investigated the effect of turmeric spice on quality of moin-moin, and the efficacy of turmeric on selected foodborne pathogens. Three samples were prepared with $(0 ; 2.5$ and $5 \mathrm{~g})$ of turmeric. Nutritional, microbial, sensory and efficacy of spice against microorganisms were performed. Moisture content ranged from (1.35 to $1.48 \%$ ), protein (38.9 to $44.9 \%$ ), ash (6.2 to $7.4 \%)$, fat (11 to $11.8 \%$ ) and fibre (6.9 to $7.7 \%$ ). TVC of samples for day zero was (3.1 to $\left.6.8 \times 10^{5} \mathrm{CFU} / \mathrm{g}\right)$; Enterobacteriaceae (1.1 to 2.1 $\left.\times 10^{5} \mathrm{CFU} / \mathrm{g}\right)$; Staphylococcal (2.7 to $\left.4.6 \times 10^{5} \mathrm{CFU} / \mathrm{g}\right)$; and Coliform (6.4 to $8.3 \times 10^{5} \mathrm{CFU} / \mathrm{g}$ ). After $48 \mathrm{~h}$, sample with $5 \mathrm{~g}$ of spice and refrigeration had reduced microbial load. Moin-moin with $2.5 \mathrm{~g}$ of turmeric was generally accepted and considered the best sample. Turmeric spice was observed to be more effective against Salmonella spp. Conclusively, addition of turmeric to moin-moin was able to reduce the microbial load and improve the shelf-life of the product.

KEYWORDS: Turmeric, Moin-Moin, Preservative, Cowpea 


\section{INTRODUCTION}

Turmeric (Curcuma longa) is a perennial plant, belonging to the family Zingiberaceae, along with other members like ginger, cardamom and galangal (Kandiannan et al., 2008). Turmeric is a native to South East Asia, an ancient spice used in medicine, in many religious observances as a cosmetic, as a dye, as food additives. It belongs to the genus Curcuma, derived from the Arabic word "turmeric" which means yellow (Ravindran, 2007), and the part of turmeric used in food and medicine is the rhizome. Curcumin, an orange-yellow crystalline powder, it is the most important fraction which is responsible for the biological activities of turmeric, it is a potent antioxidant, in that it scavenges damaging particles in the body known as free radicals, and has been reported to possess potential health benefits for numerous inflammatory diseases such as arthritis and cardiovascular disease, as well as for cancer and diabetes (Singletary, 2010).

Furthermore, turmeric has a high nutritional status that can be exploited it contains vitamins or vitamin precursor which produces vitamin $\mathrm{C}$, beta - carotene as well as polyphenol coupled with fatty acid and essential oil. Turmeric is an important component of curry and popularly consumed in Africa and some sub - Saharan countries (Chattopadhyan et al., 2004).

Cowpea (Vigna unguiculata) is a cheap source of protein, consumed as a vegetable often in combination with cereals or grains and are incorporated into a variety of recipes which are processed into various products (Odedeji et al., 2011) including akara and moin-moin (Olopade et al., 2004).

Moin-moin is an important dietary staple traditionally produced from steamed cowpea paste and popular in Nigeria and other West African countries (Ngoddy et al., 1986). Moin-moin can be consumed alone as part of diet or with other cereal based foods such as Akamu, Agidi (fermented maize porridge) with rice or gaari (cassava). It is usually packaged in different materials such as leaves, milk tin, plastic or polyethylene bags before steaming (Olayiwola et al., 2012).

The preparation of moin-moin from fresh cowpea seed is labour intensive and time consuming. Besides that, moin-moin has a short shelf life of 18-24 h (Olapade, 2004; Ayoade et al., 2012), and highly prone to spoilage.

Spices may contribute piquancy to foods and beverages (Praween and Nazia,2006), and are commonly used as natural antimicrobial agents in foods (Indu et al., 2006). Turmeric extracts have been shown to have medicinal effects such as anti-fungal activities, it is also expedient to determine the efficacy of turmeric on selected foodborne bacteria. It is believed that turmeric does not only contribute to the taste and aroma of food products it also has preservative properties. Therefore, the focus of this study is to investigate the preservative effect of turmeric in foods and its efficacy against selected foodborne pathogens. 


\section{MATERIALS AND METHODS}

\section{Source of Plant Material}

About $8.0 \mathrm{~kg}$ of harvested rhizomes of turmeric plant (Curcuma longa) and $2.0 \mathrm{~kg}$ of red beans (Vigna unguiculata) were obtained from Ojee market, Ibadan Oyo state and transported to the Food Science Department of Technology Iwo, Osun State until used. Leaves (Thaumatococcus danielli) were also procured on production day.

\section{Preparation of Turmeric (Curcuma longa) powder}

Turmeric rhizomes were cleaned, sorted, to remove dirt, debris and damaged ones and were washed with running potable water. Rhizomes were peeled, crushed and dried in the cabinet (Model F300, Chris Alex Engineering, Ibadan, Nig.) drier at $65{ }^{\circ} \mathrm{C}$ for $5 \mathrm{~h}$. After drying, the turmeric rhizome was milled using a blender (Master Chef blender MC-BL1544, China) until a smooth powder was obtained in order to ensure high surface area for increased diffusion (Manju et al., 2005). The resulting dried turmeric powder was stored in a clean air tight container in the laboratory at room $\left(25 \pm 2{ }^{\circ} \mathrm{C}\right)$ temperature until used.

\section{Preparation of Bean pudding (Moin-moin)}

The red beans (Vigna unguiculata) were cleaned and sorted to remove dirt and debris. About $1.5 \mathrm{~kg}$ of red beans sample was soaked in $2 \mathrm{~L}$ of potable water for 20 minutes after which it was dehulled. After dehulling, $1 \mathrm{~L}$ of water was added to the beans which was then wet milled in a blender (Bottom discharge hammer mill Tw- 48BD, India). Further, $2 \mathrm{~L}$ of water was added after blending and the resulting bean paste weighed $3.9 \mathrm{~kg}$. The pre-cooked cowpea paste was divided into three equal parts of $1.3 \mathrm{~kg}$ each, namely moin-moin without spice (MWOT); moinmoin with $2.5 \mathrm{~g}$ of turmeric spice (MWT1) and moin-moin with $5 \mathrm{~g}$ of turmeric spice (MWT2). Further, $25 \mathrm{~g}$ of salt and $50 \mathrm{~mL}$ of vegetable oil were added to each sample and mixed thoroughly. About $15 \mathrm{~mL}$ of the bean paste was then packaged into leaves (Thaumatococcus daniellii) for steaming. All samples were steamed for about 45 minutes then removed and left to cool. After cooling, samples were divided into two batches for storing at room $\left(25 \pm 2{ }^{0} \mathrm{C}\right)$ and refrigeration $\left(4 \pm 2{ }^{0} \mathrm{C}\right)$ temperatures in order to monitor shelf life/spoilage according to Ogundele et al., (2015).

\section{Proximate Analysis of Moin-moin Samples}

All chemical analyses were performed in triplicates

Proximate composition (Moisture, protein, ash, crude fibre and fat) was determined according to AOAC (2005). Carbohydrate was determined by difference as follows: $\%$ carbohydrate $=$ $100-[\%$ moisture $+\%$ fat $+\%$ ash $+\%$ protein $+\%$ fibre $]$

\section{Determination of Mineral Content of Moin-moin Samples}

The minerals analyzed were calcium, potassium, sodium, iron and magnesium. Mineral ash content was determined according to (AOAC, 2005). The elements, calcium (Ca) and magnesium (Mg) were determined using Atomic Absorption Spectrometer (PG 990, United Kingdom) at wavelength of $422.7 \mathrm{~nm}$ and $285.2 \mathrm{~nm}$ respectively. The element, sodium (Na) and potassium (K) were determined by flame photometry method using a flame photometer (Jenway PFP7, United Kingdom) at wavelength of $589.0 \mathrm{~nm}$ and $766.4 \mathrm{~nm}$ respectively. 


\section{Physical Analysis (Colour Determination)}

The colour of the samples was assessed by the method described by Hongbete et al (2009). The Hunter Lab colour coordinates system, $\mathrm{L}^{*}$ (Lightness) $\mathrm{a}^{*}$ (redness), $\mathrm{b}^{*}$ (yellowness) values were recorded. The Commission Internationale de l' Eclairage (CIE) tristimulus L*a*b*parameters were determined using a colour meter CR-410 (Konica Minolta, Inc., Japan). Multiple measurements (10 points) of $\mathrm{L}^{*}, \mathrm{a}^{*}$ and $\mathrm{b}^{*}$ parameters were determined by placing the sensor of the colorimeter on the sample. All measurements were done in triplicate.

\section{Microbiological Analyses}

The microbiological analyses of the dried turmeric spice and Moin-moin samples were performed on production day and $48 \mathrm{~h}$ after production and storage. The dried turmeric powder was assessed for total viable, Enterobacteriaceae and Staphylococci counts. While the moinmoin samples were assessed for total viable, Enterobacteriaceae, coliform and Staphylococci counts on production day and $48 \mathrm{~h}$ after production. Briefly, for the microbial load of the spice, $10 \mathrm{~g}$ of spice was mixed with $90 \mathrm{~mL}$ of peptone water (Himedia Lab., India) and further serially diluted up to $10^{-4}$. Using the pour plate method, $1 \mathrm{~mL}$ of last dilution was plated in plate count agar, MacConkey and Baird Parker agar (Lab. M, United Kingdom) for total viable, Enterobacteriaceae and Staphylococci counts respectively (AMPH, 1992). Similar process was followed for the moin-moin samples except Eosin methylene blue agar for Coliform count was also inoculated. Plates were incubated at $37{ }^{\circ} \mathrm{C}$ overnight and enumerated.

\section{Sensory Evaluation Test}

All samples were cut into bite size after cooling, coded and served randomly to 15-member untrained panelists. The participants were however familiar with the product and were instructed to score on a 5-point Hedonic scale, where $1=$ dislike extremely, $2=$ dislike moderately, $3=$ neither like nor dislike, $4=$ like moderately and $5=$ like very much (Meilgaard et al., 1991), based on the attributes such as appearance, aroma, taste, texture and overall acceptability. Water and crackers were made available for panel members to rinse their palates between samples to prevent carry over effect and to aid in removing flavour between tasting.

\section{Preparation of methanol turmeric extracts}

A $10 \mathrm{~g}$ of the powdered turmeric spice was soaked in $100 \mathrm{~mL}$ of mixture of methanol and water (4:1) for 96 hours. After the extraction, the mixture was filtered with muslin cloth and then concentrated to remove the entire methanol using rotary evaporator (Adebisi and Ojokoh, 2011).

\section{Preparation of bacterial inoculum}

Two Gram negative and 1 Gram positive (Salmonella spp., E. coli spp. and Staphylococcus aureus) bacteria isolates previously identified were sub-cultured in nutrient broth and incubated. Following incubation for $18 \mathrm{~h}, 5 \mathrm{~mL}$ portion of broth culture of Salmonella spp., E. coli spp. and Staphylococcus aureus was transferred into a set of eight sterile test tubes each.

\section{Determination of efficacy of turmeric spice against selected foodborne pathogens}

Following Adebisi and Ojokoh method (2011), different concentrations of the extract were prepared at 2.5, 5, 10 and $20 \mathrm{mg} / \mathrm{mL}$. Using a sterile pipette, $1 \mathrm{~mL}$ of the different concentration 
of the extract was poured into the $5 \mathrm{~mL}$ broth culture and further incubated for $24 \mathrm{~h}$ at $30{ }^{0} \mathrm{C}$. The tubes were observed for growth as indicated by turbidity and confirmed with the aid of a colorimeter at $540 \mathrm{~nm}$ wavelength.

\section{Statistical Analysis}

Data from proximate, colour, mineral and sensory analyses was analyzed using descriptive statistics, Analysis of variance (ANOVA) with a post-hoc Duncan New Multiple Range Test in IBM SPSS Statistics 23.0 version at $(\mathrm{p}<0.05)$ significant level.

\section{RESULTS AND DISCUSSION}

\section{Proximate Analysis}

Nutritional composition of the moin-moin samples are presented in the Table 1. From the results, there were significant differences $(\mathrm{p}<0.05)$ in moisture and protein contents of the samples. On dry weight basis, moisture content ranged from $(1.35 \pm 0.0$ to $1.48 \pm 0.01 \%)$ with MWOT, cowpea moin-moin (control) having the highest moisture content. Protein content ranged from $(38.9 \pm 2.8$ to $44.9 \pm 0.1 \%)$. Ash content ranged from $(6.2 \pm 0.7$ to $7.4 \pm 1.3 \%)$. The values for the crude fat ranged from $(11.0 \pm 1.2$ to $11.8 \pm 0.2 \%)$. Crude fiber content ranged from $(6.9 \pm 0.5$ to $7.7 \pm 0.3 \%)$ and carbohydrate content ranged from $(27.7 \pm 1.3$ to $33.8 \pm 5.9$ $\%)$. The moisture content values are below the range of moin-moin samples (36.10 to $44.12 \%$ ) reported by (Akusu et al., 2012). It was observed that as the concentration of turmeric powder increased, the protein, fat and crude fibre content also increased significantly $(p<0.05)$, while moisture and ash contents decreased. The crude protein content of the samples in this study are contradictory to the values (17-27\%) reported by (Otunola et al., 2018), possibly due to their addition of water yam flour. Moin-Moin without turmeric (control sample) had the least protein content and the value increased as turmeric increased. Turmeric powder contains a significant level of protein (Ikpeama et al., 2014), thereby increasing the protein level in moin-moin. The fat content in moin-moin samples corresponds to Otunola et al (2018) report of (9-10\%), but contradicts the report (15.3\%) of Akusu and Kiin-Kabari (2012). The ash content in all the moin-moin samples in this study is not significantly different. Moin-moin without spice (MWOT) has higher $\left(7.41 \pm 1.3^{\mathrm{a}}\right)$ content. Ash content is an indication of mineral contents in food (Adelakun et al., 2009). It is unclear why the ash content of samples with the addition of turmeric spice further decreased. Although ash content of turmeric has been documented to be low (Ikpeama et al., 2014). The crude fiber content was within range of the report (6.30 to 8.40 $\%$ ) of (Otunola et al (2018). Crude fiber was also observed to be highest in moin-moin $(7.71 \pm 0.3 \%)$ with high turmeric spice though, there were no significant difference between the samples. The highest value for carbohydrate was recorded in MWOT (33.75 $5.9 \%)$. Legumes are valuable source of carbohydrates; hence blends of cereal legume diet will satisfy both the protein and carbohydrate requirements of man (Maphosa and Jideani, 2017). 
Table 1: Proximate Composition of Cowpea paste (moin-moin) samples with turmeric spice

$$
\text { Proximate Content (\%) }
$$

\begin{tabular}{lllllllll}
\cline { 3 - 7 } Sample & Moisture & DM & Protein & Ash & Fat & Fiber & CHO & $\begin{array}{l}\text { Energy } \\
\text { (Kcal) }\end{array}$ \\
\hline MWOT & $1.48 \pm 0.01^{\mathrm{a}}$ & 98.5 & $38.9 \pm 2.8^{\mathrm{b}}$ & $7.4 \pm 1.3^{\mathrm{a}}$ & $11.0 \pm 1.2^{\mathrm{a}}$ & $7.5 \pm 0.6^{\mathrm{a}}$ & $33.8 \pm 5.9^{\mathrm{a}}$ & 389.15 \\
MWT1 & $1.37 \pm 0.03^{\mathrm{b}}$ & 98.6 & $40.9 \pm 0.9^{\mathrm{b}}$ & $6.2 \pm 0.7^{\mathrm{a}}$ & $11.6 \pm 0.5^{\mathrm{a}}$ & $6.9 \pm 0.5^{\mathrm{a}}$ & $33.1 \pm 2.1^{\mathrm{a}}$ & 400.23 \\
MWT2 & $1.35 \pm 0.00^{\mathrm{b}}$ & 98.6 & $44.9 \pm 0.1^{\mathrm{a}}$ & $6.5 \pm 1.0^{\mathrm{a}}$ & $11.8 \pm 0.2^{\mathrm{a}}$ & $7.7 \pm 0.3^{\mathrm{a}}$ & $27.7 \pm 1.3^{\mathrm{a}}$ & 397.04 \\
\hline
\end{tabular}

Values are mean \pm SD of triplicate; Duncan separation of means with same alphabets are not different $(\mathrm{p}<0.05)$ in each column. $\mathrm{DM}=$ Dry matter; MWOT= Moin-moin without turmeric; MWT1=Moin-moin with $2.5 \mathrm{~g}$ of turmeric; and MWT2= Moin-moin with $5 \mathrm{~g}$ of turmeric.

\section{Mineral Composition}

Mineral composition of the moin-moin samples are presented in Table 2. Inclusion of turmeric spice improved the mineral contents. There were significant differences $(p<0.05)$ in the calcium $(\mathrm{Ca})$, magnesium $(\mathrm{Mg})$, potassium $(\mathrm{K})$, Iron $(\mathrm{Fe})$ and sodium $(\mathrm{Na})$ content. Calcium content ranged from $(88.5 \pm 0.01$ to $204.3 \pm 0.07 \mathrm{mg} / \mathrm{kg}) ;$ magnesium ranged from $(207.8 \pm 0.01$ to $269.8 \pm 0.07 \mathrm{mg} / \mathrm{kg}$ ); potassium ranged from $(291.8 \pm 0.07$ to $410.0 \pm 0.07 \mathrm{mg} / \mathrm{kg})$; iron content ranged from $(151.8 \pm 0.07$ to $255.5 \pm 0.01 \mathrm{mg} / \mathrm{kg})$ and sodium ranged from $(292.3 \pm 0.07$ to $315.2 \pm 0.07 \mathrm{mg} / \mathrm{kg}$ ). Potassium content was observed to be the highest in the minerals analyzed and in agreement with the finding of Cardoso et al (2021). The calcium content from this study was low compared to Adeyeye et al (2012), who reported $(460 \pm 0.71 \mathrm{mg} / \mathrm{kg})$. MoinMoin with $5 \mathrm{~g}$ inclusion of turmeric (MWT2) had the highest value of $(204.3 \pm 0.00 \mathrm{mg} / \mathrm{kg}$ ) while the least value was in MWOT $(88.5 \pm 0.01 \mathrm{mg} / \mathrm{kg})$. Calcium is one the most important mineral that the body requires and its deficiency is more prevalent than any other mineral (Kanu et al., 2009). Moin-Moin with $5 \mathrm{~g}$ of turmeric had higher amounts of all the minerals analyzed followed by the sample with $2.5 \mathrm{~g}$. Different minerals have been documented to be beneficial to human health. For example, magnesium acts as an activator of many enzyme systems (Adeyeye and Agesin, 2007), potassium binds to protein and with sodium influences osmotic pressure and contributes to normal $\mathrm{pH}$ equilibrium (Adeyeye and Agesin, 2007). The iron content of the products ranged from $(151.8 \pm 0.07$ to $255.5 \pm 0.01 \mathrm{mg} / \mathrm{kg})$. The highest value of iron was recorded for MWT2 and within range of the results $(119-327 \mathrm{mg} / \mathrm{kg}$ ) of Adeyeye $e t$ al (2012). The sodium content in the moin-moin samples is high and could be attributable to the addition of salt in the sample preparation. But not more than the recommended average daily intake of 3,400 mg (CDC, 2017). 
Table 2: Selected mineral content of moin-moin samples with turmeric spice

\begin{tabular}{llllll}
\hline \multicolumn{5}{c}{ Mineral Content $(\mathrm{mg} / \mathrm{kg})$ of moin-moin samples } & \\
\cline { 2 - 5 } Sample & Calcium & Magnesium & Potassium & Iron & Sodium \\
\hline MWOT & $88.5 \pm 0.01^{\mathrm{c}}$ & $207.8 \pm 0.01^{\mathrm{c}}$ & $291.8 \pm 0.07^{\mathrm{c}}$ & $151.8 \pm 0.07^{\mathrm{c}}$ & $292.3 \pm 0.07^{\mathrm{c}}$ \\
MWT1 & $96.0 \pm 0.07^{\mathrm{b}}$ & $225.3 \pm 0.2^{\mathrm{b}}$ & $404.8 \pm 0.07^{\mathrm{b}}$ & $198.5 \pm 0.1^{\mathrm{b}}$ & $302.3 \pm 0.1^{\mathrm{b}}$ \\
MWT2 & $204.3 \pm 0.07^{\mathrm{a}}$ & $269.8 \pm 0.07^{\mathrm{a}}$ & $410.0 \pm 0.07^{\mathrm{a}}$ & $255.5 \pm 0.1^{\mathrm{a}}$ & $315.2 \pm 0.07^{\mathrm{a}}$ \\
\hline
\end{tabular}

Values are mean \pm SD of triplicate; Duncan separation of means with same alphabets are not different $(\mathrm{p}<0.05)$ in each column. MWOT= Moin-moin without turmeric; MWT1=Moin-moin with $2.5 \mathrm{~g}$ of turmeric; and MWT2= Moin-moin with $5 \mathrm{~g}$ of turmeric.

\section{Colour Composition of Moin-Moin Samples}

The mean values for the color intensity of the moin-moin samples are presented in Table 3 . The $\mathrm{L}^{*}$ values ranged from $(63.6 \pm 0.0$ to $72.3 \pm 0.3)$ The $\mathrm{a}^{*}$ value ranged from $(-0.69 \pm 0.07$ to $-5.2 \pm 0.07)$ and $b^{*}$ value ranged from $(7.01 \pm 0.4$ to $21.5 \pm 0.2)$. The $L^{*}$ values implies that most of the color of the moin-moin samples without turmeric (MWOT) was tending towards white while the other samples with turmeric were tending away from white (lightness) hence the $b^{*}$ value of MWOT is the lowest compared to the moin-moin samples with turmeric. The higher the concentration of turmeric used, the higher the $b^{*}$ value (Surojanametakul et al., 2010). Furthermore, the addition of turmeric increased the curcuminoid content and redness as reported by Ajayi and Bankole (2020).

Table 3: Colour composition of moin-moin samples

\begin{tabular}{llll}
\hline Parameter & $\mathbf{L}^{*}$ & $\mathbf{a}^{*}$ & $\mathbf{b}^{*}$ \\
\hline MWOT & $72.3 \pm 0.3^{\mathrm{a}}$ & $-0.69 \pm 0.07^{\mathrm{a}}$ & $7.01 \pm 0.4^{\mathrm{c}}$ \\
MWT1 & $67.8 \pm 0.1^{\mathrm{b}}$ & $-4.2 \pm 0.21^{\mathrm{b}}$ & $20.6 \pm 0.6^{\mathrm{b}}$ \\
MWT2 & $63.6 \pm 0.0^{\mathrm{c}}$ & $-5.2 \pm 0.07^{\mathrm{c}}$ & $21.5 \pm 0.2^{\mathrm{a}}$ \\
\hline
\end{tabular}

Values are mean \pm SD of triplicate; Duncan separation of means with same alphabets are not different $(\mathrm{p}<0.05)$ in each column; MWOT= Moin-moin without turmeric; MWT1=Moin-moin with $2.5 \mathrm{~g}$ of turmeric; and MWT2= Moin-moin with $5 \mathrm{~g}$ of turmeric.

\section{Microbial Load}

The microbial (TVC; Enterobacteriaceae and Staphylococcal) load for the turmeric spice are presented in Table 4. The source of microbial contaminants could be from soils, dirt from harvesting environment and inadequate washing and cleaning before milling. Microbial loads of turmeric spice were $\left(1.2 \times 10^{6} \mathrm{CFU} / \mathrm{g}\right) ;\left(1.1 \times 10^{6} \mathrm{CFU} / \mathrm{g}\right)$; and $\left(6.1 \times 10^{5} \mathrm{CFU} / \mathrm{g}\right)$ for total viable, Enterobacteriaceae and Staphylococcal counts respectively. 
Table 4.: Microbial content (CFU/g) of turmeric spice

\begin{tabular}{llll} 
Sample & Total viable & Enterobacteriaceae & Staphylococcal \\
\hline Turmeric spice & $1.2 \times 10^{6}$ & $1.1 \times 10^{6}$ & $6.1 \times 10^{5}$ \\
\hline
\end{tabular}

$\mathrm{CFU}=$ Colony Forming Unit

\section{Microbial Load of Moin-Moin sample at Day 0 and $48 \mathrm{~h}$}

On production day, total viable count for the moin-moin ranged from $\left(3.1 \pm 2.1^{\mathrm{b}}\right.$ to $6.8 \pm 5.6^{\mathrm{a}} \times 10^{5}$ $\mathrm{CFU} / \mathrm{g})$; Enterobacteriaceae count ranged from $\left(1.1 \pm 1.4^{\mathrm{b}}\right.$ to $\left.2.1 \pm 4.2^{\mathrm{a}} \times 10^{5} \mathrm{CFU} / \mathrm{g}\right)$. Staphylococcal count ranged from $\left(2.7 \pm 4.2^{\mathrm{b}}\right.$ to $\left.4.6 \pm 2.8^{\mathrm{a}} \times 10^{5} \mathrm{CFU} / \mathrm{g}\right)$. Coliform counts for the moin-moin were $\left(6.4 \pm 5.6^{\mathrm{b}}\right.$ to $\left.8.3 \pm 4.2^{\mathrm{a}} \times 10^{5} \mathrm{CFU} / \mathrm{g}\right)$ (Table 5). The presence of Enterobacteriaceae are usually indicators of post processing contamination of heat-treated food. With the addition of turmeric, it was observed that the microbial counts reduced, when compared to the control sample. After 48 hours of storage at varying temperatures, total viable count for the moin-moin sample kept at room $\left(32 \pm 2{ }^{0} \mathrm{C}\right)$ temperature ranged from $\left(7.9 \pm 1.4^{\mathrm{b}} \times 10^{5}\right.$ to $\left.1.3 \pm 2.5^{\mathrm{a}} \times 10^{6} \mathrm{CFU} / \mathrm{g}\right)$, and $\left(6.4 \pm 4.1^{\mathrm{b}}\right.$ to $\left.8.9 \pm 1.4^{\mathrm{a}} \times 10^{5} \mathrm{CFU} / \mathrm{g}\right)$. Enterobacteriaceae counts after storage were $\left(1.5 \pm 0.7^{\mathrm{b}}\right.$ to $\left.3.5 \pm 4.2^{\mathrm{a}} \times 10^{5} \mathrm{CFU} / \mathrm{g}\right)$ and $\left(4.5 \pm 0.7^{\mathrm{b}} \times 10^{4}\right.$ to $\left.1.2 \pm 0.2^{\mathrm{a}} \times 10^{5} \mathrm{CFU} / \mathrm{g}\right)$; Staphylococcal counts ranged from $\left(8.9 \pm 1.0^{\mathrm{c}} \times 10^{5}\right.$ to $\left.2.6 \pm 0.8^{\mathrm{a}} \times 10^{6} \mathrm{CFU} / \mathrm{g}\right)$ and $\left(4.1 \pm 2.1^{\mathrm{b}} \times 10^{5}\right.$ to $\left.1.6 \pm 6.3^{\mathrm{a}} \times 10^{6} \mathrm{CFU} / \mathrm{g}\right)$; and Coliform ranged from $\left(7.0 \pm 0.7^{\mathrm{c}}\right.$ to $9.0 \pm 0.7^{\mathrm{a}} \times 10^{5} \mathrm{CFU} / \mathrm{g}$ ) and $\left(5.0 \pm 2.8^{\mathrm{b}}\right.$ to $\left.7.3 \pm 1.4^{\mathrm{a}} \times 10^{5} \mathrm{CFU} / \mathrm{g}\right)$ for room and refrigeration temperatures respectively. Sample MWT2 showed a one log reduction in the microbial counts. This means the introduction of turmeric spice in moin-moin can prolong the shelf-life of the product and to further reduce the load, the moin-moin samples should be heated before consumption.

Table 5: Microbial Load (CFU/g) of moin-moin sample with turmeric during storage at room and refrigeration temperature

\begin{tabular}{|c|c|c|c|c|}
\hline \multirow{2}{*}{ Sample } & \multicolumn{3}{|c|}{ Microbial load (CFU/g) } & \multirow[b]{2}{*}{$\overline{\text { Coliform }}$} \\
\hline & TVC & Enterobacteriaceae & Staphylococcal & \\
\hline \multicolumn{5}{|l|}{ Day 0} \\
\hline MWOT & $6.8 \pm 5.6^{\mathrm{a}} \times 10^{5}$ & $2.1 \pm 4.2^{\mathrm{a}} \times 10^{5}$ & $3.5 \pm 4.2^{\mathrm{a}} \times 10^{5}$ & $8.3 \pm 4.2^{\mathrm{a}} \times 10^{5}$ \\
\hline MWT1 & $3.1 \pm 2.1^{\mathrm{b}} \times 10^{5}$ & $1.1 \pm 1.4^{\mathrm{b}} \times 10^{5}$ & $2.7 \pm 4.2^{\mathrm{b}} \times 10^{5}$ & $6.4 \pm 5.6^{\mathrm{b}} \times 10^{5}$ \\
\hline MWT2 & $5.8 \pm 2.8^{\mathrm{a}} \times 10^{5}$ & $1.1 \pm 1.4^{\mathrm{b}} \times 10^{5}$ & $4.6 \pm 2.8^{\mathrm{a}} \times 10^{5}$ & $6.6 \pm 2.1^{b} \times 10^{5}$ \\
\hline \multicolumn{5}{|c|}{48 h storage @ $\left(32 \pm 2^{0} \mathrm{C}\right)$} \\
\hline MWOT & $1.3 \pm 2.5^{\mathrm{a}} \times 10^{6}$ & $3.5 \pm 4.2^{\mathrm{a}} \times 10^{5}$ & $2.6 \pm 0.8^{\mathrm{a}} \times 10^{6}$ & $9.0 \pm 0.7^{\mathrm{a}} \times 10^{5}$ \\
\hline MWT1 & $1.0 \pm 5.6^{\mathrm{a}} \times 10^{6}$ & $1.7 \pm 1.4^{\mathrm{b}} \times 10^{5}$ & $1.5 \pm 0.8^{b} \times 10^{6}$ & $7.5 \pm 1.4^{\mathrm{b}} \times 10^{5}$ \\
\hline MWT2 & $7.9 \pm 1.4^{b} \times 10^{5}$ & $1.5 \pm 0.7^{b} \times 10^{5}$ & $8.9 \pm 1.0^{c} \times 10^{5}$ & $7.0 \pm 0.7^{c} \times 10^{5}$ \\
\hline \multicolumn{5}{|c|}{48 h storage @ $\left(4 \pm 2{ }^{0} \mathrm{C}\right)$} \\
\hline \multicolumn{5}{|c|}{ MWOT } \\
\hline MWT1 & $8.9 \pm 1.4^{\mathrm{a}} \times 10^{5}$ & $1.2 \pm 0.2^{\mathrm{a}} \times 10^{5}$ & $1.6 \pm 6.3^{\mathrm{a}} \times 10^{6}$ & $7.3 \pm 1.4^{\mathrm{a}} \times 10^{5}$ \\
\hline \multirow[t]{2}{*}{ MWT2 } & $8.1 \pm 3.5^{\mathrm{a}} \times 10^{5}$ & $1.0 \pm 1.4^{\mathrm{a}} \times 10^{5}$ & $4.7 \pm 3.5^{b} \times 10^{5}$ & $7.0 \pm 0.7^{\mathrm{a}} \times 10^{5}$ \\
\hline & $6.4 \pm 4.1^{b} \times 10^{5}$ & $4.5 \pm 0.7^{b} \times 10^{4}$ & $4.1 \pm 2.1^{b} \times 10^{5}$ & $5.0 \pm 2.8^{\mathrm{b}} \times 10^{5}$ \\
\hline
\end{tabular}

MWOT: Moin-moin without turmeric; MWT1: Moin-Moin with 2.5g of turmeric; MWT2:

Moin-Moin with 5g of turmeric; TVC: Total viable count $\mathrm{CFU}=$ Colony Forming Unit 


\section{Sensory Evaluation}

Sensory scores ranged from (2.9 \pm 0.46 to $3.6 \pm 0.00)$; ( $3.3 \pm 0.81$ to $3.7 \pm 0.88)$; $(3.0 \pm 0.84$ to $4.1 \pm$ $0.79)$; $(3.1 \pm 0.63$ to $3.4 \pm 0.98)$ and $(2.8 \pm 0.87$ to $3.9 \pm 0.00)$ for colour, aroma, taste, texture and overall acceptability. These scores were significantly different $(\mathrm{P}<0.05)$. Bean cake (moinmoin) with $2.5 \mathrm{~g}$ of turmeric (MWT1) was scored higher in colour (3.8), aroma (3.7), taste (4.1), and overall acceptability (3.9). Moin-moin without turmeric (MWOT) was scored higher only in texture and MWT2 with 5 g turmeric was scored low consistently (Figure 1).

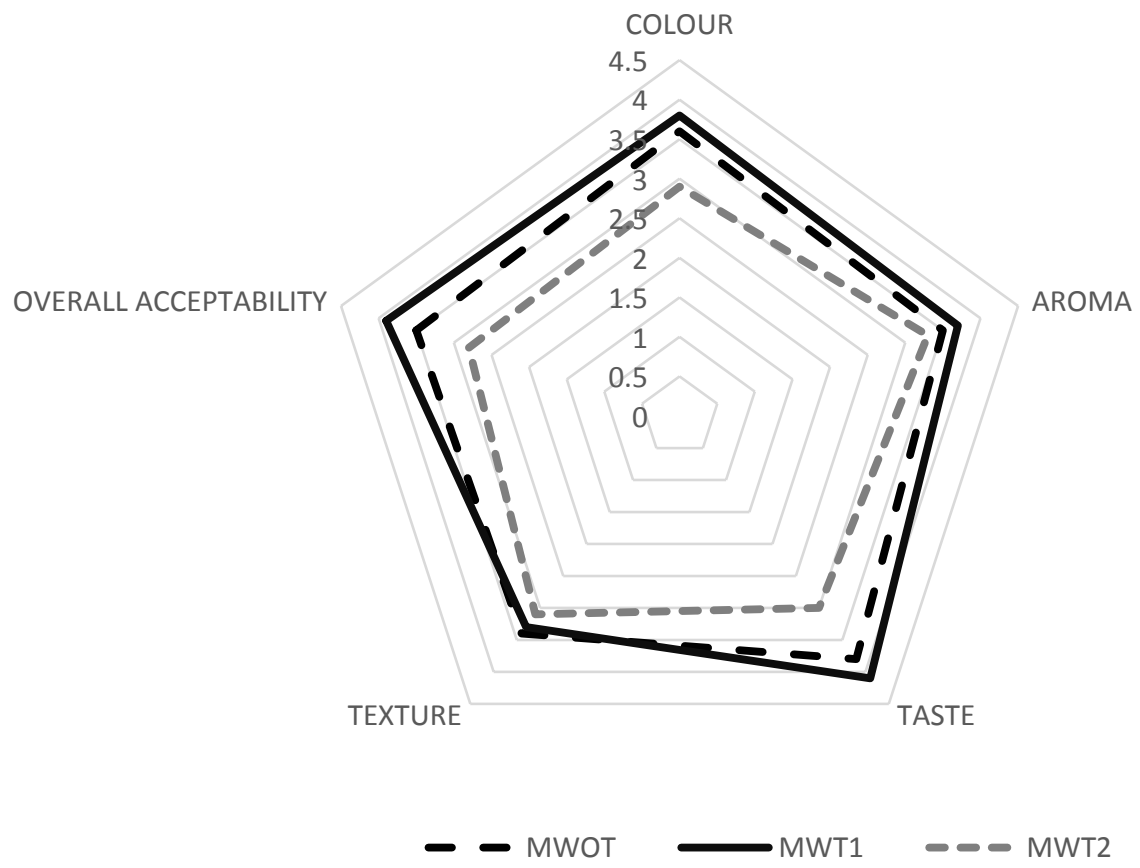

Figure 1: Values are mean scores of panelists for sensory attributes. MWOT= Moinmoin without turmeric; MWT1=Moin-moin with $2.5 \mathrm{~g}$ of turmeric; and MWT2= Moinmoin with $5 \mathrm{~g}$ of turmeric

\section{Efficacy of Turmeric Spice Against Selected Microorganisms}

Figure 2 shows the antimicrobial activity of turmeric spice extracted in methanol against Salmonella spp., Escherichia coli and Staphylococcus aureus. The spice extract minimum absorbance was (0.39); (0.38) and (0.35) at $2.5 \mathrm{mg} / \mathrm{mL}$ and maximum absorbance was (0.88); $(0.61)$ and $(0.55)$ at $20 \mathrm{mg} / \mathrm{mL}$ concentration of extract. Turmeric extract was slightly more effective against enteric microorganisms in this study, particularly Salmonella spp and less effective against Staphylococcus aureus. 


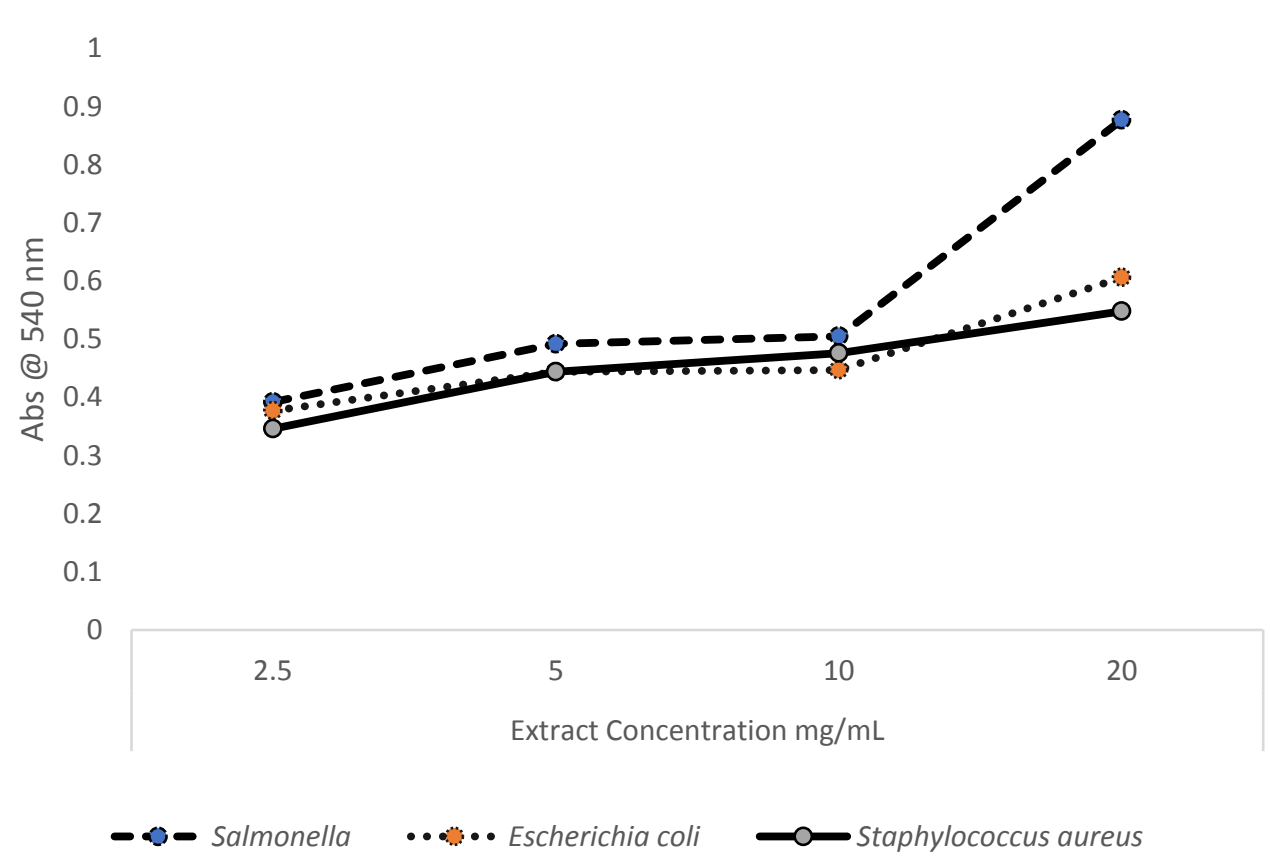

Figure 2: Efficacy of Turmeric spice against selected microorganisms at varying concentration

A Spearman rho correlation coefficient was calculated for the relationship between the various treatments and sensory attributes (colour, aroma, texture, taste and overall acceptability) of moin-moin samples. The correlation between various treatments of samples and sensory attributes was observed to be strong except aroma $(\rho(45)=-.091 \mathrm{p}<0.554)$ and texture $(\rho(45)=-$ $.232 \mathrm{p}<0.126)$. There were strong positive correlations between colour ( rho $(45)=.644^{* *}, p$ $.000)$; aroma (rho (45) $\left.=.385^{* *}, p .09\right)$; texture (rho (45) $\left.=.542^{* *}, p .000\right)$; taste (rho (45) $\left.=.767^{* *}, p .000\right)$; and overall acceptability (Table 6).

Table 6: Spearman's $\rho$ correlation between overall acceptability of moin-moin and sensory attributes

\begin{tabular}{llllll}
\hline \multicolumn{5}{c}{} & \multicolumn{3}{c}{ Sensorv Attributes } \\
\cline { 2 - 5 } & Colour & Aroma & Texture & Taste & Overall \\
acceptability
\end{tabular}




\section{CONCLUSION}

Other spices such as onion and pepper were not used to season the moin-moin samples in this study, in order to observe the effect of turmeric on the quality of the food. Study showed that turmeric spice can serve as a substitute for natural preservative or added along the other spices in indigenous foods. The moin-moin samples contain desired amounts of nutrients such as protein, carbohydrates, minerals, fat, fibre and ash. The microbial contents were either unchanged or reduced by at least 1 log during storage. Furthermore, the most acceptable moinmoin samples as shown in the sensory analysis was the moin-moin sample containing $2.5 \mathrm{~g}$ turmeric. Turmeric possesses antimicrobial activity and is more effective against various foodborne pathogens such as Salmonella spp. and Staphylococcus aureus. Further investigation on the preservative effect of turmeric spice on indigenous foods should be encouraged.

\section{REFERENCES}

Adebisi, O. and Ojokoh, A.O. (2011). Antimicrobial activities of green and red calyx extracts of Hibiscus Sabdariffa on some Microorganisms. Journal of Agriculture and Biological Sciences. 2(2): 038-042.

Adelakun, O.E. Oyelade, O. J. Ade- Omowaye, B.O. Adeyemi, I.A. and Vanderventer, M. (2009). Influence of pre- treatment on physiochemical and functional properties of a Nigeria okra seed (Albemoschus esculentus) flour. Food chem toxicol 47(3):657-661.

Adeyeye, E.I. and Agesin, O.O. (2007). Dehulling the African Yam Bean (Sphenostylis stenocarpa) Seeds. Bangladesh J. Sci. Ind. Res. 42(2): 163- 174.

Adeyeye, E. I. Orisakeye, O.T. Oyarekua, M. A. (2012). Composition, mineral safety index, calcium, zinc and phytate interrelationships in four fastfoods consumed in Nigeria. Bulletin of the Chemical Society of Ethiopia. 26(1):43-54.

Ajayi, O.A. and Bankole, T.I. (2020). Preservative effects of ginger (Zingiber officinale), tumeric (Curcuma longa) extract and citric acid and pasteurization on the nutritional quality and shelf life of tiger-nut non-dairy milk. Journal of Food Technology Research. 7(2): 202-211.

Akusu, O. M. and Kiin-Kabari, D. B. (2012). Protein quality and sensory evaluation of moinmoin prepared from cowpea/maize flour blends. African Journal of Food Science. 6(3): 47-51.

American Public Health Association. (1992). Compendium of methods for the microbiological examination of foods. Washington DC.

Andrews J. M (2001) Determination of minimum inhibitory concentrations Department of Microbiology, city Hospital NHS Trust, Birmingham B18 7QH, UK

AOAC (2005). Official Methods of Analysis, Association of Official Analytical Chemists, 16th ed. Washington D.C.

Cardoso, L. A. Greiner, R. Alves, A. S. B. Santos, S.R. C. dos Santos, W. P. C. Ribeiro, P. R. and de Almeida, D.T. (2021). Content of minerals and antinutritional factors in moinmoin (steamed cowpea food). African Journal of Food Science. 15(2): 72-80.

Center for Disease Control (CDC) (2017). GET THE FACTS: Sodium and the Dietary Guidelines. National Center for Chronic Disease Prevention and Health Promotion Division for Heart Disease and Stroke Prevention. Available at: https://www.cdc.gov $>$ salt $>$ pdfs > sodium dietary Accessed in May, 21, 2021. 
Chattopadhyay, I. Biswas, K. Bandyopadhyay, U. and Banerjee, R. K. (2004). Turmeric andcurcumin: Biological actions and medicinal applications. Curr Sci. 87: 44-50

Gislene, G.F.N. Juliana, L. Paulo, C. F. and Giuliana, L.S. (2000). Antibacterial Activity of Plant Extracts and Phytochemicals on Antibiotic Resistant Bacteria. Brazilian J. Microbiology. 31: 247-256.

Hongbete, F. Mestres, C. Akissoe, N. and Nago, M. C. (2009). Effect of processing conditions on cyanide content and colour of cassava flours from West Africa. Africa Journal of Food Science, 3(1), 001-006.

Ikpeama, A., Onwuka, G. I. and Nwankwo, C. (2014). Nutritional Composition of Tumeric (Curcuma longa) and its Antimicrobial Properties. International Journal of Scientific and Engineering Research. 5(10): 1085-1089.

Indu, M. N. Hatha, A.A.M. and Abirosh, C. (2006). Antimicrobial Activity of Some of the South-Indian Spices Against Serotypes of Escherichia Coli. Brazilian Journal of Microbiology. 37:153-158.

Kandiannan, K. Thankamani, C. K. Srinivasan, V. Rajeev, P. (2008). Turmeric (Extension Pamphlet), Indian Institute of Spices Research.

Kanu, J. K, Sandy, E. H. and Kandeh, B. A. (2009). Production and Evaluation of Breakfast Cereal- Based Porridge Mixed with Sesame and Pigeon Peas for Adults. Pak J. Nutr. 8(9): 1335-1343.

Maphosa, Y. and Jideani, V. A. (2017). The Role of Legumes in Human Nutrition Functional Food - Improve Health through Adequate Food. 103-121

Meilgaard, M. C., Carr, T. B., and Civille, G. V. (1991). Sensory evaluation technique (2nd ed.). Florida: CRC Press. Boca Raton.

Ngoddy, P.O. Enwere, N. J. and Onuorah, V. I. (1986). Cowpea flour performance in Akara and Moi-Moi preparations. Tropical Science 26:101 - 119.

Odedeji, J.O. Oyeleke, W. A. (2011) Proximate, Physicochemical and Organoleptic Properties of Whole and Dehulled Cowpea Seed Flour (Vigna unguiculata). Pakistan Journal of Nutrition. 10: 1175-1178.

Ogundele, G.F. Ojubanire, B.A. Bamidele, O. P. (2015). Determination of the pasting and functional properties of cowpea (Vigna unguiculata) and soybean (Glycine max) Blends, British Journal of Applied Science and Technology. 6:304-309 DOI: 10.9734/BJAST/2015/11663

Olapade, A. Okafor, G. I. Ozumba, A. U. and Olatunji, O. (2002). Characterization of common Nigerian cowpea (Vigna unguiculata L. Walp) varieties. Journal of Food Engineering. 55: 101-105.

Olapade, A. A. Ugokwe, P. U. Ozumba, A.U. Solomon, H. M. Olatunji, O. and Adelaja S.O. (2004). Physico-chemical properties of premixes for preparation of akara. Nigerian Food Journal. 22: 54-59.

Olayiwola, O. A. Shittu, S. A. Adebayo, O. R. (2012). Evaluation of heavy metals in three common Nigerian Cowpea (Vigna unguiculata) paste end product ("Moinmoin') using different packaging materials. International Journal of Environmental Sciences. 3(2): 833-840.

Okunola, G.A. and Afolayan, A. J. (2018). Evaluation of the physicochemical, proximate and sensory properties of moinmoin from blends of cowpea and water yam flour. Food Science and Nutrition. 6: 991-997.

Perween, T. and Nazia, M.A.C. (2006). Bactericidal Activity of Black Pepper, Aniseed and Coriander Against Oral Isolates. Pakistan J. Pharmaceutical Sciences. 19(3): 214-218. 
Ravindran, P. N. (2007). Turmeric - The Golden Spice of Life in Turmeric: the genus Curcuma edited by P.N. Ravindran, K. Nirmal Babu, and K. Sivaraman. (Medicinal and aromatic plants--industrial profiles, v. 45), CRC Press.

Singletary, K. (2010). Turmeric; An overview of potential health benefits. Nutrition Today. 45(5):216-225

Surojanametakul, V. Satmalee, P. Saengprakai, J. Siliwan, D. and Wattanasiritham, L. (2010). Preparation of Curcuminoid Powder from Turmeric Root (Curcuma longa Linn) for Food Ingredient Use. Kasetsart J. (Nat. Sci.). 44(1): 123-130. 